\title{
Palm Oil Fuel Ash as A Cement Replacement in Concrete
}

\author{
Jonida Pone, Ahmed Ash*, John Kamau and Fraser Hyndman \\ Department of Civil Engineering Group, Leeds Beckett University, UK

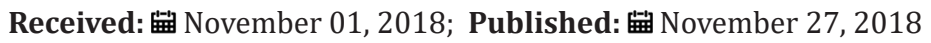 \\ *Corresponding author: Ahmed Ash, Department of Civil Engineering Group, Leeds Beckett University, UK
}

\begin{abstract}
To produce concrete, cement is an essential material that binds together solid bodies but also is the largest producer of carbon dioxide $\left(\mathrm{CO}_{2}\right)$ emission. Up to $10 \%$ of global $\mathrm{CO}_{2}$ emission comes from cement production thus making the sustainability of concrete a major issue that needs addressing. The processes of producing concrete consume heavily on natural resources such as sand, gravel, water, coal and crushed rock, mining of which damages the environment. It is however possible, that energy and cost efficiency can be achieved by reducing on the amount of clinker, and in its place utilizing partial cement replacements/pozzolans that require less process heating and emit fewer levels of carbon dioxide. This study investigates the effectiveness of agro waste ash by-product Palm Oil Fuel Ash (POFA) as an alternative material to replace Portland cement (OPC). Experiments were carried out by supplementing CEM I cement by weight in concrete mixes with POFA at $2.5 \%, 5 \%, 10 \%, 15 \%$ and $20 \%$ steps at the point of need, with water to cement ratio of 0.5 . Results were compared with a control specimen, which was made with $100 \%$ cement. The results showed impressive compressive strength, especially at early age; in fact POFA specimens containing 2.5\% and 5\% POFA replacement displayed greater early compressive strength in comparison to the control, which is similar in behaviour to concrete containing silica fume which is an established partial cement replacement used in high strength applications. The results showed good repeatability and highlight the potential of POFA as an effective pozzolan which could enhance the sustainability and economic aspect of concrete.
\end{abstract}

\section{Introduction}

Sustainability haswidely emergedinrecentyearstoresistclimate change and pollution caused by ineffective waste management. The cement industry, as one of the fundamental materials industries, plays a very important role in the social and economic development as well as imposes a great challenge in terms of its large consumption of natural resources and energy and the emission of greenhouse gases. Cement is one of the main constituents in concrete and is thus one of most utilized commodities in the world [1]. From an environmental perspective, the production of 1 tonne of cement directly generates about 1 tonne of $\mathrm{CO}_{2}$ [2]. Cement production is therefore responsible for $7-10 \%$ of the world's total CO2 emissions; compare this to the aviation industry, which is $2.8 \%$, three times less than the production that comes from cement industry [3-8]. As a result, the use of supplementary cementing materials (SCMs), like pulverised fuel ash (PFA) and ground granulated blastfurnace slag (GGBS) have been established over the past 30 years as they not only reduce the embodied $\mathrm{CO} 2$ of concrete, the long-term strength and durability is improved. Both PFA and GGBS are waste products from the coal and steel industry; due to the recent decline of both these industries, focus has shifted on other alternative SCMs. One potential alternative from agricultural waste is POFA. POFA is ash obtained by incinerating the by-products of palm oil mill. The tall-stemmed oil palm tree belongs to palm family Palmea and the countries that cultivate oil palm are Benin Republic, Colombia, Ecuador, Nigeria, Zaire, Indonesia and Malaysia of which the last one is the largest producer of palm oil and palm oil products [9]. In Malaysia the total solid waste generated by this industry in about two hundred palm oil mills has been estimated at about ten million tons a year. These by- products are commonly used as fuel in the boiler of palm oil mills and become ash. The ash is a waste material the disposal of which poses enormous environmental pollution because the ash is usually disposed of without any commercial return $[7,9,10]$ in the Far East millions of tonnes of waste is generated annually. It has been suggested [11] POFA may have pozzolanic qualities, however, very little research has been done in this area. This paper investigates the plausibility of POFA as a pozzolanic addition in concrete.

\section{Methods}

Palm Oil Fuel Ash was sourced from Malaysia. The cement used was Portland cement- CEM I 52.5R (Snow Crete). Cement was 
replaced with POFA in concrete by volume at steps of $0 \%, 2.5 \%$, $5 \%, 10 \%, 15 \%$ and $20 \%$. The $0 \%$ replacement, also referred to as the control was taken as the point of reference from which all performance was measured. Water to cement ratio (WCR) of 0.5 was used for the mixes to achieve a good balance of workability and strength in line with Abram's law which states that the strength of concrete mix is determined by the WCR, with lower WCR having higher strengths and vice-versa [12]. The quantities of each mix were measured as detailed in Table 1 . Workability was measured using the slump test method, whose apparatus were a slump cone and a tamping rod conforming to BS EN 12350-2:2009 [13]. Cube moulds for compressive measured $100 \mathrm{~mm}$ x $100 \mathrm{~mm}$ x $100 \mathrm{~mm}$, whereas cylinder moulds for tensile strength testing were $150 \mathrm{~mm}$ in diameter and $300 \mathrm{~mm}$ in height, conforming to dimensional guidelines of BS EN 12390-1:2012 [14]. The method used to make cubes conformed to BS EN 12390-2:2009 [15]. Cylinders conformed to BS EN 12390-4:2000 [16]. The specimens were left on the moulds for 24 hours after which they were stripped, marked and Table 1: Proportions of POFA concrete mix using CEM. submerged in a water tank at temperatures of $20^{\circ} \mathrm{C} \pm 2$ until their age of testing conforming to BS EN 12390-2:2009 [15]. Specimens were cured for up to 28 days. Compressive strength tests were conducted to BS EN 12390-4:2000 [16]. After the application of an initial load of $0.6 \pm 0.2 \mathrm{~N} / \mathrm{mm}^{2} . \mathrm{s}$, which, according to BS EN 12390-4:2000 [16] does not exceed $30 \%$ of the failure load, further constant load was applied at a rate of $\pm 10 \%$ until no further load could be sustained. Compressive tests were carried out at 7 and 28 days. Results were taken as an average of the three cubes per test, and expressed in $\mathrm{N} / \mathrm{mm}^{2}$.Tensile strengths were conducted to BS EN 12390-6:2009 [17]. The testing machine conformed to BS EN 12390-4:2000 [16] while packing strips conformed to BS EN 316:2009 [18]. Initial load was applied at a constant rate of stress of $0.04 \mathrm{~N} / \mathrm{mm}^{2} . \mathrm{s}$, which, according to BS EN 12390- 6:2009 [17] does not exceed 20\% of the failure load. Further constant load was thereafter applied at a rate of $\pm 10 \%$ until no further load could be sustained. As POFA is a very fine low- density material the cement was replaced by weight and at lower percentage, similar dosage to Silica Fume.

\begin{tabular}{|c|c|c|c|c|c|}
\hline $\begin{array}{c}\text { Composition with } \\
\text { POFA replacement }\end{array}$ & Cement (kg) & POFA (kg) & $\begin{array}{c}\text { Coarse Aggregates } \\
\text { (kg) }\end{array}$ & Fine Sand (kg) & Waters (litres) \\
\hline Control & 6.5 & 0.00 & 19.5 & 6.5 & 3.2 \\
\hline $2.5 \%$ & 6.4 & 0.08 & 19.5 & 6.5 & 3.2 \\
\hline $5 \%$ & 6.2 & 0.16 & 19.5 & 6.5 & 3.2 \\
\hline $10 \%$ & 5.9 & 0.33 & 19.5 & 6.5 & 3.2 \\
\hline $15 \%$ & 5.5 & 0.49 & 19.5 & 6.5 & 3.2 \\
\hline $20 \%$ & 5.2 & 0.65 & 19.5 & 6.5 & \\
\hline
\end{tabular}

Results and Discussion

\section{Compressive strength}

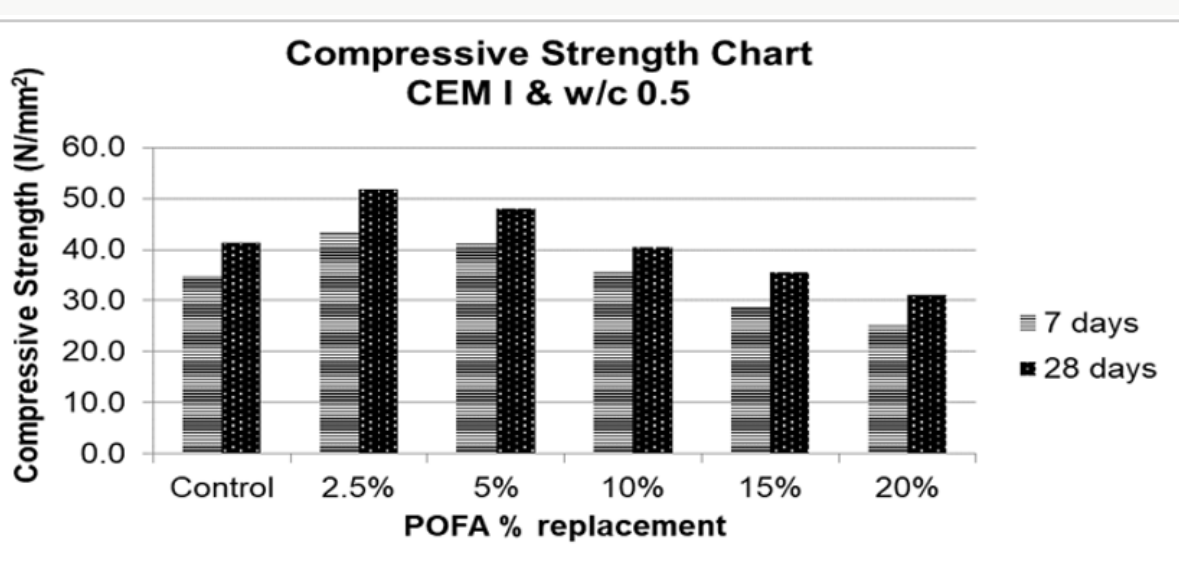

Figure 1: Compressive strength Development Chart (CEM I and w/c 0.5).

Compressive strength is the most important property of concrete, and it measures how much load concrete structures can sustain before failing. (Table 2) and (Figure 1) show the compressive strengths at 7 and 28 days of hardened concrete with $0 \%, 2.5 \%, 5 \%, 10 \%, 15 \%$ and $20 \%$ POFA replacement. Replacements of up to $10 \%$ achieved strengths that were above the targeted class C32/40 at 28 days, is among strength classes listed by BS EN 1992-1-1: 2004 [19] and BS 8500-1:2015 [20], as being suitable for structural applications. It is possible to predict the higher replacements could achieve strengths that are far above this class strength at 91 days or longer, due to the fact that pozzolanic concrete continue to gain strength up to and beyond 91 days. Palm 
Oil Fuel Ash can also be used as an alternative to cement in highway pavement as the minimum 28-day compressive cube strength requirement using pozzolans for highway pavements in the UK is $9.6 \mathrm{~N} / \mathrm{mm} 2$. Therefore $2.5 \%, 5 \%$ and $10 \%$ replacement of POFA is sufficient to use in highway pavement and road construction. It is worth noting, as POFA is a very fine and low-density material, a $10 \%$ partial cement replacement constitutes a large volume of POFA, similar to silica fume. Like similar fume [21] at low percentage cement substitution of up to 5\% POFA yields greater early age strengths in comparison to the control. In limited work reported elsewhere, other researchers $[7,9,11]$ found the optimum level of replacement to be at 15\%-20\% which are different results from this research. The findings suggest that Palm Oil Fuel Ash is an effective pozzolan to replace cement at low percentages. The $2.5 \%$ and 5\% POFA replacements had remarkable high early strength concrete compare to the control one. According to [22,23], the early age strength is due to the hydration of cement, with POFA acting as a filler of voids and contributing to the strength gain, while the latter age strength in pozzolanic concrete is associated with the reaction of $\mathrm{SiO} 2$ present in the POFA with free lime $\mathrm{Ca}(\mathrm{OH}) 2$ from the hydration of cement in a secondary reaction over time, to form calcium silicate hydrate (C-S-H). The optimum replacing level of cement by POFA is at $2.5 \%$. This amount of replacement could be effective in large projects where large amounts of OPC are used and an early high compressive strength is required. The replacement of OPC with POFA helps in decreasing the pollution as well as has many economic benefits. Palm Oil Fuel Ash particle size can be compared to that of silica fume and therefore could have similar applications to silica fume especially in terms of mix design. It can be used in high-strength concrete and could include long span bridges, mainly of precast and prestressed girders to allow for longer span in structural bridge design and high-rise sky scrapers by building smaller columns and increasing usable space.
Table 2: Compressive strength for POFA using (CEM I and w/c $0.5)$.

\begin{tabular}{|c|c|c|}
\hline \multicolumn{3}{|c|}{ Compressive Strength $\left(\mathbf{N} / \mathbf{m m}^{2}\right.$ ) } \\
\hline & $\mathbf{7}$ days & $\mathbf{2 8}$ days \\
\hline Control & 35 & 41 \\
\hline $2.5 \%$ & 44 & 52 \\
\hline $5 \%$ & 42 & 48 \\
\hline $10 \%$ & 36 & 40 \\
\hline $15 \%$ & 29 & 36 \\
\hline $20 \%$ & 26 & 31 \\
\hline
\end{tabular}

\section{Tensile strength}

(Table 3) and (Figure 2) show the tensile strength results for POFA concrete at 28 days, the tensile strength initially increases with increasing POFA replacement up to $5 \%$ then subsequently decreases at higher levels; this trend is not consistent with the general behavior of PCRs [22-26] whereby the tensile strength decreases with increasing amount of PCRs.

Table 3: Tensile strength for POFA using (CEM I and w/c 0.5).

\begin{tabular}{|c|c|}
\hline \multicolumn{2}{|c|}{ Tensile strength $\left(\mathrm{N} / \mathrm{mm}^{2}\right)$} \\
\hline & 28 days \\
\hline Control & 3.3 \\
\hline $2.5 \%$ & 4.1 \\
\hline $5 \%$ & 3.8 \\
\hline $10 \%$ & 3.2 \\
\hline $15 \%$ & 2.8 \\
\hline $20 \%$ & 2.5 \\
\hline
\end{tabular}

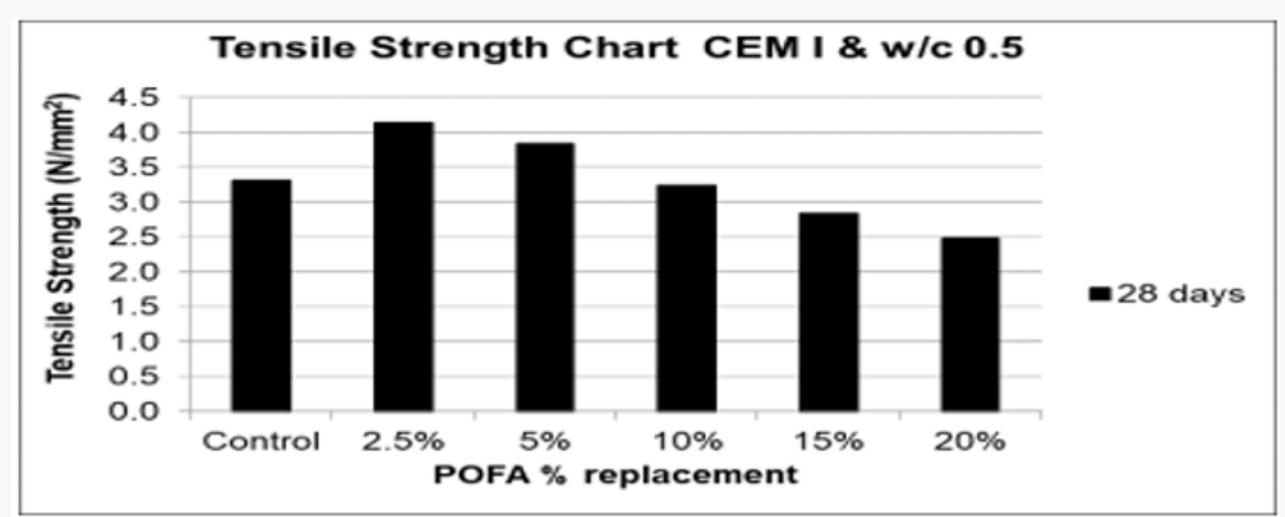

Figure 2: Tensile Strength of POFA replaced concrete at 28 days.

\section{Workability}

Table 4 and Figure 3 show the slumps of POFA replaced mixes at different replacement levels. One of the basic attributes of any cementitious material is its workability or "consistence", which is largely determined by how wet the concrete is. This is referred to as "slump". Basically, the wetter the concrete, the higher the slump. Although slump is often seen as an indication of water content, it is more reasonably interpreted as a measure of consistence. 
Consistency is a term that describes the state that concrete is when it is delivered on site, how easily can fresh concrete flow. Concrete is said to be workable when it is easily placed and compacted homogenously, however workability is very difficult to assess. Slump test is the most well-known method to examine the characteristics of concrete workability. It is used to measure the consistency of concrete as well. The slump test values depend on a variety of factors such as types and properties of concrete ingredients. Workability of POFA concrete was observed to decrease with increasing replacement; this is due to the high-water demand of POFA which can be countered by the use of admixtures. Like with silica fume [21], the water demand of concrete containing POFA increases with increasing amounts of POFA. This increase is caused primarily by the high surface area of the palm oil fuel ash.

Table 4: Slump readings for POFA mixes.

\begin{tabular}{|c|c|c|}
\hline Mix using CEM I and w/c 0.5 & Slump values (mm) & Slump Class \\
\hline Control & 150 & S3 \\
\hline $2.5 \%$ & 110 & S3 \\
\hline $5 \%$ & 100 & S3 \\
\hline $10 \%$ & 90 & S3 \\
\hline $15 \%$ & 35 & S1 \\
\hline $20 \%$ & 15 & S1 \\
\hline
\end{tabular}

Slump of POFA mixes against percentage replacement $(\mathrm{mm})(\mathrm{CEM} I$ and $\mathrm{w} / \mathrm{c} 0.5)$

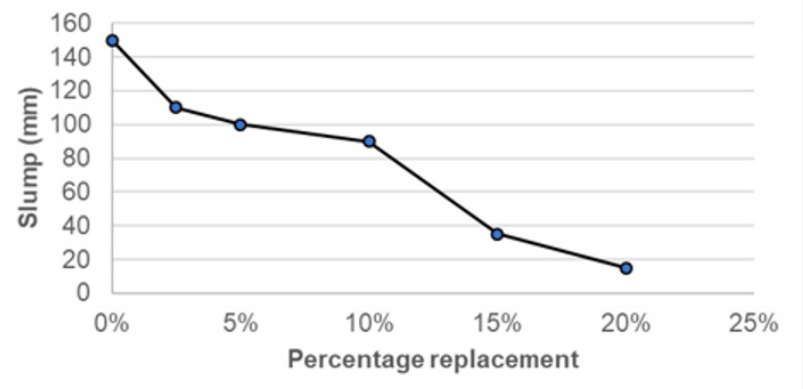

Figure 3: Workability of POFA replaced mixes.

\section{Conclusion}

The usage of partial cement replacements or pozzolans is gaining popularity for a variety of reasons including enhancing concrete performance, reducing the cost of using traditional concrete ingredients and serve the environment. Cement production is one of the highest contributors to $\mathrm{CO}_{2}$ emission. Partial cement replacements not only confer environmental benefits, but they also have a positive impact on concrete properties. This study investigated the effect of Palm Oil Fuel Ash as a pozzolan replacement in concrete and the main findings are:

a) Palm Oil Fuel Ash is an effective pozzolan to replace cement at low percentages with the optimum level is at $2.5 \%$

b) Specimens made with $2.5 \%$ and 5\% POFA replacement had higher strengths compared to the control at 7 and 28 days; very similar behaviour to silica fume

c) Workability decreases with increased amount of POFA unlike with PFA and GGBS concrete; like silica fume POFA has a high-water demand.

d) Based on strength findings, palm Oil Fuel Ash concrete have the potential to be used in superstructures including long span bridges, mainly for precast and prestressed girders to allow for longer spans in structural bridge design and high-rise sky scrapers by building smaller columns and increasing.

\section{References}

1. US Geological Survey (2017) Global cement production top countries 2016 | Statistic. [online].

2. Mineral Products Association (2007) Fact Sheet 18 [Part 1] Embodied $\mathrm{CO}_{2}$ of UK Cement. Additions and Cementitious Material p. 8.

3. Rao KJ, Mujeeb MA, Sastri M (2014) Behavior of Ternary Blended Concrete with Fly Ash and Silica Fume IUP Journal of Structural Engineering 7(2): 25.

4. Johnson ME, Gonzalez (2013) Estimating Cost Savings for Aviation Fuel and $\mathrm{CO}_{2}$ Emission Reductions Strategies. Collegiate Aviation Review 31(2): 79-102.

5. Unfccc int (2018) Climate Change Information Sheet 3.

6. Bapat JD (2012) Mineral admixtures in cement and concrete. CRC Press, USA.

7. Sooraj V (2013) Effect of Palm Oil Fuel Ash (POFA) on Strength Properties of Concrete. International Journal of Scientific and Research Publications 3(6): 7.

8. Center C (2018) Specifying sustainable concrete, s.l: mpa.

9. Deepak T, Albarra E, Noor H, Chakravarthy N, Mithun B (2014) Investigation on Properties of Concrete with Palm Oil Fuel Ash as a Cement Replacement. International Journal of Scientific \& Technology Research 3(1): 138-142.

10. Zarina Y, Mustafa Al Bakri A, Kamarudin H, Khairul I, Rafiza A (2012) Review on the various ash from palm oil waste as geopolymer material. Rev Adv Mater Science 1(34): 37-43.

11. Premalatha, KR Vinodh L Chris Anto, R Nithiya (2016) Properties of Palm Ash Concrete. International Journal of Engineering Science Invention 5(8): 29-32. 
12. Oluokun FA (1994) Fly ash concrete mix design and the water-cement ratio law. Materials Journal 91(4): 362-371.

13. British Standards Institution (2015) BS EN 12350-2:2009 Testing fresh concrete. Part 2: Slump test. London.

14. British Standards Institution (2012) BS EN 12390-1:2012. Testing hardened concrete Part 1: Shape, dimensions and other requirements for specimens and moulds. London.

15. British Standards Institution (2009) BS EN 12390-2:2009. Testing hardened concrete. Part 2: Making and curing specimens for strength tests. London.

16. British Standards Institution (2000) BS EN 12390-4:2000. Testing hardened concrete Part 4: Compressive Strength-Specification for testing machines. London.

17. British Standards Institution (2010) BS EN 12390-6:2009. Testing hardened concrete Part 6: Tensile splitting strength of test specimens. BSI, London, UK.

18. British Standards Institution (2010) BS EN 316:2009. Wood fibre boards-Definition, classification and symbols. BSI, London, UK.

19. British Standards Institution (2010) BS EN 1992-1-1: 2004: Eurocode 2: Design of Concrete Structures, Part 1-1: General Rules and Rules for Buildings. British Standards Institution (BSI), London, UK.
20. British Standards Institution, "BS 8500-1 (2015) ConcreteComplementary British Standard to BS EN 206. Part 1: Method of specifying and guidance for the specifier. British Standards Institution (BSI), London, UK.

21. King D (2012) The Effect of Silica Fume on the Properties of Concrete as Defined in Concrete Society Report 74, Cementitious Material, 37th Conference on Our World in Concrete \& Structures: 29-31.

22. Bapat J (2017) Mineral admixture in cement and concrete. s.l.:CRC Press.

23. Shetty M (2006) Concrete technology: theory and practice. revised ed. s.l.:S Chand Publishing.

24. Ahmed, A, Hirst P, Kamau J, Kangwa J (2016) Suitability of corncob ash as a supplementary cementitious material. International Journal of Materials Science and Engineering 4(4): 215-228.

25. Adesanya D, Raheem A (2008) Development of corn cob ash blended cement," Construction and Building Materials 23(1): 347-352.

26. Ahmed A (2017) Influence of Rice Husk as Density on the Workability and Srength of Structural Concrete. European Journal of Engineering Research and Science 2(3): 36-43.

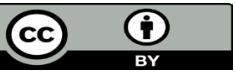

This work is licensed under Creative Commons Attribution 4.0 License

To Submit Your Article Click Here:

Submit Article

DOI: $10.32474 /$ MAMS.2018.01.000102

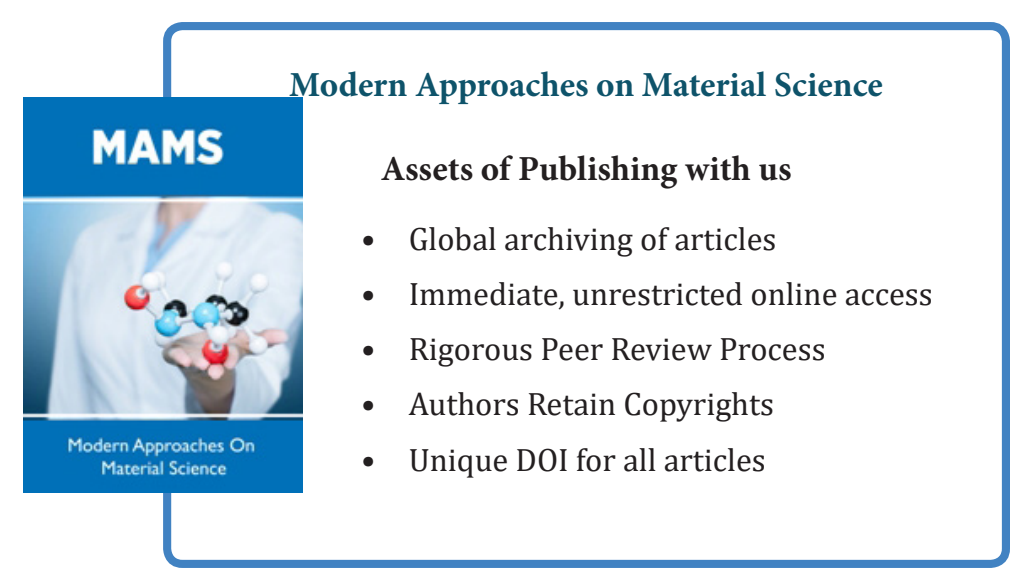

